\title{
CONCEITO MÉDICO-FORENSE DE MORTE
}

\author{
Maria Celeste Cordeiro Leite dos Santos \\ Professora Associada do Departamento de Filosofia e Teoria Geral do \\ Direito da Faculdade de Direito da Universidade de São Paulo
}

Resumo:

O ser humano seja ele um homem, uma mulher, ou uma criança, é formado por dois intrincados componentes, porém, conceitualmente distintos: a entidade biológica e a pessoa. Por isso, costuma-se afirmar que o ser humano pode ter mais de uma morte: a denominada morte biológica e a morte jurídica. A morte biológica é a cessação de todos os processos biológicos e constitui uma irreversível perda de toda a unidade biológica. As razões para termos distintos critérios de morte são as de diagnosticar a morte e as de pronunciar uma pessoa morta. A sociedade poderá, então, realizar suas cerimônias fúnebres, seus ritos religiosos, funerais, etc., aceitando a chamada morte biológica. Os bens e propriedades são distribuídos, os seguros reclamados, a sucessão tem lugar, bem como os demais procedimentos legais. Também o transplante de órgãos pode ocorrer, o que implica em difíceis e complexas decisões bioéticas. O critério de Havard, de 1968, estabeleceu como critério de morte, a morte encefálica. Atualmente, existem várias controvérsias sobre esse critério.

Abstract:

An human being is a man, woman, or child who is a composite of two intricately related but conceptually distinguishable components: thebiological entity and the person. Therefore, human beings can suffer more than one death: a biological death and decay, and another death. Biological death is a cessation of process of biological synthesis and replication, and is an irreversible loss of integration of biological units. The reasons for having criteria for death are to diagnose death and pronounce a person death. Society can then begin to engage in grief, religious rites, funerals and accept biological death. Wills can be read, property distributed, insurance claimed, succession can take place, and legal proceedings can begin. Also, organ donation can take place, which entails difficult bioethical decisions. The Harvard criteria of 1968 were devised to set forth brain -death criteria with whole brain death in mind. Currently, there are several controversies regarding these criteria

Unitermos: entidade biológica; pessoa; morte biológica; morte jurídica. 
Sumário:

Introdução.

1. O problema do conceito.

2. Conceito jurídico de morte.

3. Conceito médico-jurídico de morte.

4. Tanatologia. Critérios de morte.

5. Perspectiva histórica.

6. Classificação médico-legal das formas de morte.

7. Fenômenos cadavéricos.

8. Morte rápida ou súbita e morte lenta.

9. Morte natural.

10. Morte violenta.

11. Morte suspeita.

12. Morte sem assistência. Diagnóstico de morte. Morte encefálica. Legislação aplicável.

Conclusões.

Introdução.

A morte do homem como destino final e inexorável transcende o mero processo biológico para levantar importantes repercussões. A mensagem da ressuscitação da morte é relevante para notarmos que a vida e a morte são interdependentes: existem de forma simultânea e não-consecutiva. Os estóicos diziam que "a morte é o fato mais importante da vida"; e entre os romanos Cícero, proclamava que: "Filosofar é preparar-se para a morte" e para Seneca "ninguém desfruta o verdadeiro gosto para a vida, até que esteja pronto para abandoná-la" Santo Agotinho expressou a mesma idéia: "O verdadeiro ser do homem nasce para a morté

O limite biológico entre a vida e a morte pode ser preciso, mas do ponto de vista psicológico ambas se fundem. A morte é um fato da vida e não o seu último momento. Morremos desde o nascimento, o final está presente desde o princípio. Ela é incomparável. Martin Heidegger (1926) e Jasper (que posteriormente denominou-a de situação limite), afirmavam ser "a condição que nos permite viver a vida de maneira autêntica" Freud acreditava que a transitoriedade 
da vida aumenta o desfrute que experimentamos com a morte. Sustentou, ainda, que possuímos dentro de nós um instinto voltado para a vida (instinto de vida Eros) e um instinto voltado para a morte (instinto de morte - Tanatos). Mostramos uma patente inclinação a prescindir da morte, a eliminá-la da vida. Tentamos silenciá-la, medicalizá-la, evangelizá-la, legalizá-la e enquanto pudermos continuaremos sendo meros espectadores. Ninguém crê na própria morte.

A morte possui riquíssima importância no sentido de nossa existência: sabemos que somos mortais mas, somos beneficiados pelo desconhecimento do momento de nossa morte; em decorrência, lança-mô-la no indefinido, ou seja, no infinito e, em conseqüência, vivemos como se fôssemos imortais... - sabendo que não o somos. Qualquer aproximação da morte determina substanciais alterações no sentido de nossas vidas. Da mesma forma, a capacidade humana para a virtualidade, isto é, a capacidade de transformar o espaço-tempo real em espaço-tempo subjetivo, proporciona que, com o passar da idade, progressivamente, vamos lançando a velhice e a morte cada vez mais para a frente; caso contrário, viver transformar-se-ia em esperar a morte.

Seria simples continuarmos enumerando citações sobre a morte. Somos criaturas mortais que conhecemos nossa mortalidade, porque possuímos uma consciência de nós mesmos. Negar a morte a qualquer nível é negar a natureza básica do homem. O nosso medo de morrer é permanente e de tal magnitude que uma parte de nossa energia vital é consumida na tarefa de negar a morte. O homem constantemente busca transcendê-la. A personalidade do homem está inseparavelmente conectada à sua unidade (corpo e alma ou consciência).

Perante a lei, os médicos devem firmar um atestado de óbito, ou uma declaração de óbito. Para o professor dr. Marco Segre (Compêndio de Medicina Legal, 1987), escrito em co-autoria com o dr. Hilário Veiga de Carvalho e outros, "o atestado de óbito tem por finalidade certificar a existência da morte e registrar a sua causa, quer do ponto de vista médico, quer de eventuais aplicações jurídicas para permitir o diagnóstico da causa juridica do óbito: seja o homicídio, o suicídio, acidente ou a morte chamada natural"

Por vezes, as coisas mais simples e óbvias são as mais difíceis de conceituar e definir. É o que acontece com a morte, sempre rodeada de incertezas, dúvidas, temores e superstições. Trata-se de um fenômeno complexo que pode ser analisado sob diferentes ângulos: como fenômeno social, histórico, biológico, antropológico, bioético, religioso, cultural, médico e legal. Nas últimas décadas, os 
estudiosos de Bioética tem se esforçado no sentido de clarificar, do ponto de vista técnico-científico, este tão-delicado momento.

Dada a magnitude do tema escolhido optamos por abordarmos especificamente uma proposta de reforma conceitual da morte, tendo em vista que os problemas médico-legais hoje existentes são questões conceituais, mais do que técnicas.

1. O problema do conceito.

A palavra "conceito", "concepto", "concepção", "conceição" envolve um juízo filosófico e lógico. Kant estabelecia o conceito como algo idealizado, gerado, concebido, convencionado.

Ensina o professor doutor Marcos de Almeida, em seu trabalho: Morte: uma nova proposta de reforma conceitual, que, "em filosofia, a palavra 'conceito' (da qual concepção é a equivalente mais antiga), é extensamente empregada. Na realidade é tão-conveniente a ponto de ser quase indispensável, apesar de seu uso algumas vezes ter suscitado dificuldades... Um aspecto proeminente do processo do pensamento humano é a utilização da abstração, em que categorias generalizadas são utilizadas para representar uma diversidade de objetos particulares e eventos. As idéias gerais para classes de itens são designadas conceitos e o processo pelo qual alguém vem dar a resposta comum (geralmente um nome), a uma classe geral de coisas que, apesar de diferir nos detalhes, tem certas características comuns, é chamado formação de conceitos. Diferentemente do conceito de doença, o conceito de morte não pode ser determinado exclusivamente pelo critério biológico. Isto pelo fato de que está relacionado com as crenças filosóficas mais gerais relativas ao significado da vida e da morte. O conceito de morte envolve necessariamente um julgamento filosófico de que ocorreu uma alteração muito importante e significativa, o que pressupõe uma idéia de condições indispensáveis de vida" 
2. Conceito Jurídico de Morte.

Em Hermenêutica Jurídica o conceito de morte é um conceito aberto, assim considerado porque seus elementos constitutivos são dados pela ciência médica, mas sua interpretação é jurídica.

$\mathrm{O}$ conceito de morte interessando às diversas ciências biológicas, médicas, jurídicas e sociais, está longe de ter um consenso do momento real de sua ocorrência. Assim sendo, o Direito não define o que seja a morte, nem o que seja a vida. É preciso, porém, fazermos uma distinção entre a morte, o morrer e o morto.

\section{Conceito Médico-Jurídico de Morte.}

O professor dr. Irany Novah Moraes em seu artigo "A morte vista do espelho" (Jornal da USP, 3 a 9 de março de 1997, p. 2) afirma que a morte nunca é instantânea, há um intervalo de tempo entre a instalação e a sua consumação. "Tratando-se de processo evolutivo, pode-se distinguir a morte do morrer. Enquanto ela é o final da vida, este é a sua progressão no organismo. Tal período é conhecido como agonia e temido pelo sofrimento que geralmente o acompanha. A essência da morte está na ativação da catepsina, ocorrida pela ausência de oxigênio, ou seja, pela anóxia. A diminuição de oxigênio determina autólise, ou seja, sua autodigestão e, assim, a morte. Inicialmente, morre a célula, depois o tecido e, a seguir, o órgão; trata-se de um fenômeno em cascata. Estabelecido o processo, ele pode atingir os órgãos, dos quais depende a vida do indivíduo, os chamados órgãos vitais. Desta forma, desencadeia-se a parada da respiração, do coração, da circulação e do cérebro"

$\mathrm{O}$ organismo se mantém vivo à custa da morte de milhões de células que se renovam constantemente num processo vital de contínuo equilíbrio.

É que a morte, observada desde o ponto de vista biológico, e atentando-se para a corpo, como um todo, não é um fato único e instantâneo, é antes o resultado de uma série de processos, de uma transição gradual. Com efeito, levando-se em consideração a diferente resistência vital das células, tecidos, órgãos e sistemas, que integram o corpo à privação de oxigênio, forçoso é admitir que a morte é um verdadeiro "processo incoativo" que passa por diversos estágios no devir do 
tempo. A Medicina Legal, segundo Derobert (Signes et Diagnostic de la mort, in: Médicine Légale, pp. 155/161) adotou uma etapa desse processo como seu critério de morte, o conceito tradicional da chamada morte clínica. Até pouco tempo uma das grandes questões era poder determinar se uma pessoa, realmente, estava morta ou se encontrava em um estado de morte aparente. Tudo isto visando evitar a inumação precipitada. $\mathrm{O}$ fato assumiu tal importância que chegou a influenciar os legisladores que colocaram na legislação prazos mínimos para a implementação de certos procedimentos como a necropsia e o sepultamento.

\section{Tanatologia.}

O professor doutor Moacyr da Silva em seu Compêndio de Odontologia Legal, recentemente editado nos ensina que "Tanatologia" provém do termo grego thánatos, morte, e logia, ciência, significando a ciência que estuda a morte e os fenômenos a ela relacionados.

Thanatos era um deus grego, irmão de Hipnos, deus do sono, em cujas asas as pessoas eram levadas. O que observamos em comum entre eles é o estado de inconsciência apresentado, tanto no sono, quanto na morte.

$\mathrm{Na}$ mitologia a morte aparece como a figura de uma caveira encapuçada com um manto negro, trazendo nas mãos uma foice com a qual pretende ceifar a vida das pessoas. Os pintores a retratam sob diferentes ângulos, desde o século XVI até o barroco alemão e espanhol. É famoso o quadro em que uma jovem ao olhar-se no espelho, é surpreendida pelo reflexo de um casal de idosos que se encontra às suas costas, cuja imagem, é vista como duas caveiras.

Hoje essa macabra figura foi, segundo Steven Miles, David C. Thomasma e Thomasine Kushner (Birth to Death. Science and Bioethics, 1996), substituída pelo moderno e técnico relógio da morte. Isto ocorre porque o complexo médico legal de sua determinação é um dilema e não um sintoma. O curso e as condutas utilizadas para a sua constatação são largamente determinadas pelas leis. A morte não é mais um conceito fácil de se construir.

A afirmação de que um indivíduo está vivo ou morto, depende do entendimento que se tenha desse conceito de morte. O conceito pode variar segundo diferentes culturas, religiões ou enfoques científicos. Entendemos que, qualquer mudança na definição do conceito de morte traz consigo mudanças correspondentes 
aos critérios e provas diagnósticas do estado de morte. Estes critérios só podem ter um verdadeiro significado se derivarem de um conceito apropriado e inequívoco. É preciso evitar a anômala situação em que: segundo alguns critérios estaria o indivíduo morto; e vivo, de acordo com outros critérios.

\section{Critérios de Morte:}

Em Medicina se estabelecem critérios que definem a morte. Critérios, segundo o professor titular doutor Marcos de Almeida, só tem significado, se se pode demonstrá-los como "logicamente derivados do conceito apropriado de morte" É portanto sem sentido, usar critérios "flutuantes" que não sejam derivados de um conceito de morte definido. Somente um conceito que especifique a perda irreversível de certas funções (devidas à destruição do substrato anatômico), podem evitar situações anômalas de um paciente estar vivo por um critério e, ao mesmo tempo, morto por outro... A definição médica e legal da morte mudou, há menos de trinta anos, da parada da função cardiorrespiratória, para a chamada morte neurológica. Embora estas alterações tenham sido sancionadas pela maioria das autoridades médicas e juridicas, persiste um clima de muita controvérsia, reflexo do desarranjo conceitual da literatura sobre o que se deva entender por morte.

Em matéria de conhecimento diz, Rubens Limongi França ( $O$ conceito de morte, diante do Direito ao Transplante e do Direito Hereditário, RT 717, 1995), tudo é impreciso e provisório, sub censura e sub conditione. Louvando-se nos professores Almeida Júnior e Costa Júnior (Lições de Medicina Legal,1978), lê-se que morte "é o estado do ser humano, quando já não pode sobreviver por suas próprias energias, cessados os recursos médicos por um tempo suficiente" Conforme ainda a lição desses mestres. "isso se evidencia, averiguado o silêncio cerebral e concomitantemente, a parada respiratória em caráter definitivo" Tratase de um conceito dito "tradicional de morte" e como se pode aquinhoar, existem aí elementos relevantes que cumpre ressaltar, para melhor compreensão crítica da matéria.

$A b$ initio, parece-nos que a morte, é a desintegração do dinamismo vital, psicológico; sociológico e cultural do indivíduo humano, em Direito denominado Pessoa (do latim persona, ae) de modo total e irreversível. Ou como diz Daniel Callahan: "There is nothing more that can be done" A morte da pessoa e a morte médica precisam ocorrer juntas, a dignidade da pessoa humana deve ser preservada. 


\section{Colocação de Problema:}

Término da Pessoa

"Entendendo-se que a existência da pessoa natural termina com a morte, tem-se que admitir que o morto não é pessoa e sim coisa" (França: 1992), o que não dispensa o nosso respeito, nossa piedade e nossa reverência, trata-se, nãoobstante, de "coisa fora do comércio" O morto, CAro DAta VERmibus: cadáver, carne dada aos vermes; em sentido mais restrito, o corpo morto. A Tanatologia Forense é especificação legal dessa ciência. Para não adentrarmos de maneira menos oportuna todo o cipoal desses variados aspectos da matéria, havemos por bem examinar como a história da ciência médica e jurídica considera a morte e se o conceito de morte deverá ser o mesmo para ambas.

\section{Perspectiva Histórica.}

A primeira definição clássica dos signos do falecimento no ser humano se deve a Hipócrates (500 a.C., in: DE MORBIS, segundo livro, seção 5), onde descreve as modificações do rosto no período imediato post mortem, de cuja descrição ficou conhecida a expressão "facies hipocrática" Para os gregos a morte era determinada pela parada cardíaca. Não-obstante, Hipócrates já atribuísse a razão, a emoção e a sensação ao cérebro, era o coração o indicador de vida ou morte.

Para a tradição judaico-cristã, era o pulmão o indicador do critério de morte. A pessoa estava morta quando exalava o último suspiro (pneuma).

Para eles a vida humana é sagrada e o seu término prematuro é inaceitável. Um segundo de vida é tido como equivalente a cèm anos de vida.

No século XVII, encontramos a primeira definição científica de morte com Marie François-Xavier Bichat (Recherche sur la vie et la mort, Paris), que afirmava ser a morte um processo cronológico que conduz a uma catástrofe fisiológica. Para o autor não existe o instante da morte, mesmo que seja identificado com a cessação dos batimentos cardíacos, ou com a ausência de movimentos respiratórios (o último suspiro), ou de destruição traumática do sistema nervoso central. Desde então ficou conhecida a denominada trípode de Bichat, em que as funções vitais do organismo humano são sustentadas pelo coração, pulmão e cérebro. O homem está morto quando está morta a trípode vital íntima, correlativa e 
reciprocamente vicariante, Bichat já distinguia "a vida orgânica" da vida "animal", ou, sensação e vontade do cérebro.

Grande parte do impulso para o estudo dos signos de morte basearamse na pressão social que exigia respostas fiáveis e válidas ao problema do diagnóstico de morte. Em 1742 Bruhier publicou a obra, Les incertudes des signes de la mort et le abus des enterrements et des embausemements precipités, recolhendo 189 casos de supostos enterramentos em vida. Foram criadas em 1793, na Alemanha e Itália, as chamadas câmaras mortuárias de espera. A Academia da França decidiu em 1837 estabelecer um prêmio aos trabalhos consagrados a esse tema. O prêmio foi obtido por Bouchut, com seu Traité des signes de la mort et des moyens de prévenir les enterrements prématures (1849). Hoje os prazos exigidos pela maioria das legislações, inclusive a nossa,..é no mínimo de 24 horas para se efetivar as inumações. O regulamento dos cemitérios do Município de São Paulo Ato n. 326 de 21.3.32, registra em seu art. 16 que:

"Art. 16 Os enterramentos não podem, como regra, ser feitos antes de 24 horas do falecimento, salvo em casos especiais de moléstias contagiosas ou epidemias, ou ainda, se o cadáver apresentar sinais inequivocos de princípio de putrefação"

Quando a praxis médica e a teoria jurídica tentaram fixar o processo de falecimento, simbolizado pela morte, ficou claro que o desaparecimento da função circulatória e respiratória de forma definitiva, era o signo inconfundível da não-possibilidade de um "retorno à vida" Deste modo, acreditou-se encontrar um limite final juridicamente praticável da proteção da vida, que correspondia ao estado das possibilidades médicas de então. Com o desenvolvimento das modernas técnicas de reanimação e com a possibilidade de ressuscitação da atividade do coração e pulmão, surgiram objeções contra o conceito clássico de morte. É digno notarmos que este conceito não-fracassou, apenas a reversibilidade do processo se enriqueceu. A objeção decisiva contra o chamado conceito clássico de morte, acha-se em outro âmbito. As distintas células do corpo humano têm "um tempo de reanimação diferente" isto é, o período de sobrevivência sem o afluxo de sangue oxigenado é consideravelmente diverso segundo as diferentes espécies de células. Por exemplo, o cérebro morre dentro de três a quatro minutos na falta da circulação (exceção feita em crianças recém-nascidas ou muito pequenas, cujo tempo pode ser de oito a 
quinze minutos). Outros órgãos, como o fígado e rins, sobrevivem de trinta minutos até uma hora e meia; as córneas em até seis horas, os espermatozóides em até dois dias. No encéfalo os danos são irreparáveis. Após um tempo, mais ou menos largo todas as atividades vitais cessam.

A evolução da Medicina e os avanços tecnológicos apresentam, no momento atual, novos problemas, novos temores e dúvidas, como ocorre com o diagnóstico de morte encefálica.

Uma vez que a morte é um fenômeno complexo, os critérios para sua determinação podem ser mais ou menos aplicáveis a um determinado campo das ciências médicas, jurídicas e sociais. Em Medicina Legal, podemos fazer uma classificação de suas formas, pela sua certeza (real e aparente); pela sua rapidez (lenta e rápida); por sua causa (natural, violenta, compreendendo o suicídio, homicídio e os acidentes, e duvidosa compreendendo a morte súbita, sem assistência e suspeita).

\section{Classificação Médico Legal das Formas de Morte.}

A morte não é um ponto final na existência humana, mas um elemento constitutivo dela. Situa-se mesmo, no fio direto da evolução humana. É essencial compreender a morte como um processo que, dependendo da intensidade e qualidade da agressão que a desencadeia, terá uma duração diferente, porque está constituída por uma sucessão evolutiva de fases de desestruturação progressiva do funcionamento integrado do organismo como unidade biológica. Estas fases não estão definidas claramente em seus limites, mas se confundem entre si, sem solução de continuidade, não se podendo precisar quando acaba uma fase e começa outra.

No trânsito da vida para a morte, do organismo como um todo, podemos reconhecer estágios intermediários concorrentes ou sucessivos, conforme o caso.

a. Morte aparente segundo Thoinot (1913), pode ser definida como um estado transitório em que as funções "aparentemente" estão abolidas, em conseqüência de uma doença ou entidade mórbida que simula a morte. Nestes casos que também podem ser provocados por acidentes ou pelo uso abusivo de substâncias depressoras do sistema nervoso central, a temperatura pode cair sensivelmente e ocorre um rebaixamento das funções cardiorrespiratórias de tal ordem que oferecem, ao simples 
exame clínico, a aparência de morte real. É inconteste que a vida continua, porém seus sinais externos são imperceptíveis. Há perda de consciência, imobilidade, insensibilidade, ausência aparente de respiração, ausência de circulação, midríase paralítica. A duração deste estado aguçou a curiosidade dos pesquisadores, indo desde alguns minutos até dias. Sua causa é variada, podendo ser sincopal (perturbações encefálicas, metabólicas, cardiovascular, vascular central, etc.); histérica (letargia e catalepsia); asfíctica (mecânica e não-mecânica); tóxica (por utilização de morfina ou heroína em doses tóxicas, por anestesia,...); apopléctica; traumática; elétrica; térmica; e por causas gerais (segundo Vibert - 1900) a morte aparente pode ser observada em formas terminais de cólera e em algumas formas de epilepsia.

b. Morte relativa quando ocorre parada efetiva e duradoura das funções nervosas, respiratórias e circulatórias. É possível, porém a reanimação com manobras terapêuticas extraordinárias. É para Gisbert Calabuig, J.A. (Medicina legal y toxicologia, 1994, 4a ed.) "um prolongamento da agonia"

c. Morte intermediária - é a extinção progressiva das atividades biológicas, sem que seja possível, de qualquer forma, recuperar a vida do organismo de forma unitária.

d. Morte absoluta - esta fase corresponde ao desaparecimento de toda a atividade biológica referida ao organismo primitivo.

Estas fases não estão definidas claramente em seus limites, mas para Luna Maldonado (Diagnóstico de la muerte cierta, 1994) se sobrepõem umas as outras, sem solução de continuidade, razão pela qual não se pode precisar quando acaba uma fase e começa outra.

Acerca do processo de morte existem várias possibilidades diagnósticas, dependendo do momento em que se queira estabelecer o diagnóstico (Time Factor). Ao nos aproximarmos do hipotético ponto de não-retorno, em função das circunstâncias do caso, chegamos ao chamado estado de morte absoluta ou real, cujo diagnóstico será feito na presença de signos de morte derivados dos fenômenos cadavéricos. 


\section{Fenômenos Cadavéricos.}

Já C. Simonin (Medicina Legal Judicial) afirmava que: "para o médico legista, o cadáver é o testemunho mudo de um fato judicial ou banal. Este apresenta no corpo, ou nas vísceras, vestígios reveladores que permitem 'fazê-lo falar"' Suas investigações compreendem estudos importantes sobre fenômenos cadavéricos, levantamento do cadáver, sua identificação, casos de morte súbita, ou agônica, ..., que exigem técnicas particulares de ordem anatômica, física, toxicológica, biológica.

- A manutenção da vida exige um equilíbrio biológico e físico-químico - químico; a morte é o resultado da ruptura desse equilíbrio. O corpo, inerte, sofre ações de ordem física, química e microbiana que determina os chamados fenômenos cadavéricos.

Para se verificar a certeza da morte, é necessária a observação cuidadosa desses fenômenos que, Borri metodicamente divide em: a. Fenômenos Abióticos, Avitais, ou Vitais negativos e b. Fenômenos Transformativos ou de positivação da morte.

a. Fenômenos abióticos, por sua vez, se dividem em imediatos e consecutivos. Alguns desses sinais isoladamente não tem valor absoluto.

Fenômenos Abióticos Imediatos:

- Perda da consciência.

- Perda da sensibilidade,.estão abolidas as sensações táteis, térmicas e dolorosas. Cessa a sensibilidade geral e especial.

- Abolição da motilidade e do tono muscular. A "fácies hipocrática" pode ser observada: presença de "fronte enrugada e árida, olhos fundos, nariz afilado com orla escura, têmporas deprimidas, vazias e enrugadas, maçãs deprimidas, queixo enrugado e seco, pele seca e lívida, cílios e pêlos do nariz e das orelhas semeados por poeira brancacenta, semblante carregado e desconhecido"

- Cessação da respiração. Pode ser evidenciada pela ausculta pulmonar com ausência de murmúrios vesiculares. Uma prática antiga consistia em colocar um espelho diante da boca e do nariz e, em caso de embaciamento, admitia-se o sinal 
de vida. Era uso também a aproximação de uma vela acesa; são processos de pouco valor no diagnóstico de certeza da morte.

- Cessação da circulação. A ausculta do coração (sinal de Bouchut), a eletrocardiografia são elementos preciosos na caracterização do fenômeno da morte. Surgem no globo ocular modificações várias determinadas pela parada da circulação, dilatação das pupilas ou midríase paralítica, causada pelo relaxamento do pilórulo da íris.

\section{Fenômenos Abióticos Consecutivos:}

Diferentemente dos sinais abióticos imediatos que surgem no próprio instante do óbito, os sinais mediatos ou consecutivos, que vão se instalando progressivamente, de maneira paulatina, podendo ser verificados somente após transcorrido um certo tempo.

- Desidratação. O cadáver sujeito às leis físicas sofre a evaporação tegumentar, que se traduz por: decréscimo de peso, (mais acentuado nos fetos e recémnascidos, alcançando até $8 \mathrm{~g}$ por quilograma de peso em um dia, somados nas primeiras horas). Deve-se levar em conta que este fenômeno varia de indivíduo para indivíduo, de acordo com o tipo de morte e variações ambientais. Pergaminhamento da pele - por efeito da evaporação tegumentar, a pele se desseca, endurece e torna-se sonora à percussão. Dessecação das mucosas dos lábios - principalmente nos cadáveres de recém-nascidos e de crianças, a mucosa dos lábios sofre desidratação, tornando-se dura e de tonalidade pardacenta. Achatamento do globo ocular, formação de tela viscosa, perda da tensão do globo ocular; perda da transparência da córnea; mancha negra da esclerótica sinal de Sommer e Larcher. A córnea, poucas horas depois da morte, perde sua transparência e se torna turva.

- Esfriamento do corpo (equilíbrio térmico). Com a morte, a tendência do corpo é equilibrar sua temperatura com o meio ambiente. A renovação do ar e a temperatura ambiente roubam calor, influenciando na marcha do esfriamento do cadáver. Na prática, esse esfriamento paulatino não segue uma curva assintótica, se inicia com um pequeno platô, durante o qual o declínio térmico é mínimo. Quatro mecanismos físicos contribuem para processar a perda de calor do corpo: convecção, radiação, condução e evaporação. Quanto maior for o panículo 
adiposo do cadáver, mais resistência oferece à baixa temperatura. Crianças e velhos esfriam mais facilmente que os adultos. Roupas e ambientes fechados proporcionam resfriamento mais lento do que outras circunstâncias. No morto as temperaturas axilar e retal diferem de $2^{\circ}$ a $5^{\circ} \mathrm{C}$, entre duas a doze horas após a morte. O resfriamento é lento até três horas após a morte, rápido nas próximas seis horas e, em seguida, lento novamente (Arbenz). Em ambiente de $24^{\circ} \mathrm{C}$, o equilíbrio se estabelece dentro de aproximadamente 22 horas (Flamínio Fávero). A maior ou menor rapidez de esfriamento depende de vários fatores: idade, constituição, causa-mortis, vestes, umidade, temperatura ambiente, hipotermia, etc.

- Hipóstases. É o fenômeno pós-mortal da deposição do sangue nas partes declivosas do cadáver por força da atuação da gravidade. Destarte, o sangue acaba acumulando-se, por congestão passiva, naquelas regiões que, pelas eventuais circunstâncias do momento ocupam a posição mais declive. Isto tanto é válido para a pele, quanto para os órgãos internos. Ao exame externo se evidencia, de vinte a trinta minutos após a morte, sob a forma de um fino pontilhado arroxeado denominado sugilação hipostática. Aos poucos, este fino pontilhado transforma-se em manchas maiores, de coloração cada vez mais escura, atingindo o máximo de intensidade e extensão por volta de 12 a 15 horas após o óbito. Sua fixação se dá entre oito a doze horas. Mudado o cadáver da posição em que primitivamente se encontrava, as manchas hipostáticas também se mudarão. Essa mudança não será total, deixando vestígios nas primitivas zonas de aparecimento. Este fenômeno é conhecido como migração das hipóstases. Ultrapassadas as primeiras dozes horas, as mudanças de posição do corpo não mais se acompanham de modificações na localização dos libores. Diz-se, então, que ocorreu a fixação das hipóstases. Nas hipóstases incisando a pele e o tecido celular, observa-se o gotejamento do sangue dos vasos venosos. Sua lavagem torna o tecido branco. Nas equimoses, com esse procedimento, verifica-se o sangue infiltrado nos tecidos. As manchas de hipóstases viscerais encontram-se principalmente nos pulmões, rins, intestinos e encéfalo.

- Rigidez cadavérica (rigor-mortis). É o fenômeno que alcança as massas musculares, determinando modificações químicas (ATP e estado de hidratação das fibras musculares). O tempo decorrido entre o decesso e o aparecimento das primeiras manifestações de rigidez cadavérica, muito embora possa ser variável, 
gira em torno de duas horas. Inobstante, tempos menores ou maiores podem ser detectados, aceitando-se que o tempo mínimo é de trinta minutos. Obedecendo à chamada Lei de Nysten a rigidez cadavérica aparece na seguinte ordem: músculos mandibulares, do pescoço, do tórax, dos membros superiores, do abdome e dos membros inferiores. O seu desaparecimento, por sua vez, obedece à mesma ordem de seu aparecimento. Decorridas 36 horas do óbito, em média, o processo de resolução da rigidez, já se instalou e completou. A rigidez é, portanto, um fenômeno físico-químico num estado de contratura muscular, devido à ação dos produtos católitos do metabolismo, correspondente a uma situação de vida residual do tecido muscular. Sua importância médico-legal não se restringe apenas ao diagnóstico de morte, mas também à determinação da data da morte, embora esteja sujeita a exceções apresentadas por elementos extrínsecos e intrínsecos.

- Espasmo cadavérico. Caracteriza-se pela rigidez abrupta, generalizada e violenta, sem o relaxamento muscular que precede a rigidez comum, também chamada rigidez cadavérica cataléptica, estuária ou plástica. Os cadáveres guardam a posição em que foram surpreendidos pela morte.

b. Fenômenos transformativos: Podem ser de duas ordens: destrutivos (autólise, putrefação e maceração) e conservadores (mumificação, saponificação $e$ calcificação)

- Fenômenos destrutivos. Ocorrendo a cessação da vida, desde logo começa a produzir-se a lise das células, seguida da decomposição dos tecidos e das transformações morfológicas do próprio corpo.

1. Autólise. Cessada a circulação, as células deixam de receber, pela corrente plasmática, novos elementos, prejudicando as trocas nutritivas e sofrendo, pela ação dos fermentos, a acidificação, dando início à decomposição. O meio vivo é neutro. No momento em que surge a mais leve acidez, a vida se torna impossível. Tal fenômeno é resultante da predominância de íons de $\mathrm{H}$ sobre os íons $\mathrm{OH}$ nos tecidos e líquidos dos cadáveres. A variação de $\mathrm{PH}$ dos tecidos é um sinal evidente de morte.

2. Putrefação. Após a autólise, começa a putrefação por fenômenos biológicos e físico-químicos provocados por germens aeróbicos, anaeróbicos e facultativos. É o intestino o ponto de partida da putrefação, com exceção dos recémnascidos e fetos. Nestes a putrefação invade o cadáver por todas as cavidades do 
corpo por via externa, principalmente pelas vias respiratórias. A marcha normal da putrefação varia conforme a ação de fatores intrínsecos (idade, causa mortis, constituição) e fatores extrínsecos (temperatura, aeração). A putrefação é mais rápida nos recém-nascidos e nas crianças do que nos adultos. A constituição física (os obesos se decompõem com mais rapidez), a idade, influências patológicas, a causa mortis, são condições que modificam a evolução da putrefação. A primeira manifestação objetiva e visível da putrefação é a chamada mancha verde abdominal. De ordinário aparece no abdome, iniciando-se pela fossa ilíaca direita. A localização na fossa ilíaca direita é explicada, devido ao fato de ser o ceco a parte mais dilatada e mais livre do intestino grosso e por ser o segmento que mais acumula maior quantidade de gases, se encontrando mais próximo da parede abdominal. A princípio tem uma extensão reduzida e sua cor é verde claro ou ligeiramente azulada. Daí difunde-se por todo o abdome, pelo tórax, cabeça e membros. Sua tonalidade vai escurecendo até atingir o verde enegrecido, dando ao cadáver um tom bastante escuro. Esta fase da putrefação é conhecida como a fase ou período cromático. Embora não haja uma rigorosa precisão, a putrefação segue uma determinada evolução, passando por quatro períodos: período de coloração; período gasoso; período coliquativo e período de esqueletização.

O período de coloração ou cromático, como vimos acima, iniciase pela mancha verde abdominal. Nos afogados, o período de coloração começa pela cabeça e parte superior do tórax (devido à posição assumida pelo cadáver submerso).

No período gasoso do interior do corpo, vão surgindo os gases da putrefação, com bolhas na epiderme, de líquido hemoglobínico. O cadáver toma um aspecto gigantesco, principalmente na face, no abdome e nos órgãos genitais masculinos, dando-lhe a posição de lutador. Esses gases fazem pressão sobre o sangue que foge para a periferia e, pelo destacamento da epiderme, esboça na derme o desenho vascular conhecido como circulação póstuma de Brouardel. Sais de chumbo neutro evidenciam a presença desses gases.

Período coliquativo. Esta fase se manifesta pela dissolução pútrida do cadáver, cujas partes moles vão pouco a pouco reduzindo-se de volume pela desintegração progressiva dos tecidos. Surge um grande número de larvas e insetos nesta fase. Este período varia de acordo com as condições do corpo e do terreno, podendo ir de um a vários meses.

Período de esqueletização. A atuação do meio ambiente e dos elementos faz com que o cadáver se apresente com os ossos quase livres, presos 
apenas pelos ligamentos articulares. Os ossos resistem por muito tempo, porém, vão perdendo pouco a pouco, sua estrutura habitual, tornando-se cada vez mais frágeis e leves.

3 Maceração. É um processo especial de transformação que sofre o cadáver do feto no útero materno, do sexto ao nono mês de gravidez. Esse fenômeno pode ser séptico, de acordo com as condições do meio onde o corpo permanece. Fetos retirados do útero post mortem sofrem maceração asséptica. Os cadáveres mantidos em meio líquido sob a ação de germes, como os afogados, marcham para a maceração séptica. Como característica, observa-se no cadáver, o destacamento de amplos retalhos de tegumentos cutâneos que se assemelham a luvas. A epiderme se destaca facilmente e pode até rasgar-se em grandes fragmentos. $\mathrm{O}$ corpo perde a consistência, o ventre se achata e os ossos se livram dos tecidos ficando como se estivessem soltos.

Fenômenos conservadores:

Saponificação ou adipocera. É um processo transformativo conservador que se caracteriza pela modificação do cadáver em substância de consistência untuosa, mole e quebradiça, de tonalidade amarela escura, dando uma aparência de cêra ou sabão. Surge depois de um estágio mais ou menos avançado de putrefação. É raro encontrar um cadáver totalmente transformado por esse fenômeno especial. Mais comum é encontrar um cadáver com pequenas partes ou segmentos limitados, constituídos em adipocera. Esse fenômeno pode surgir espontaneamente, sendo porém a água e o solo os responsáveis. A água estagnada e pouco corrente, o solo argiloso, úmido e de difícil acesso ao ar atmosférico facilitam o processo. $\mathrm{Na}$ adipocera, a análise química revela a presença de ácidos graxos: ácido palmítico, esteárico e em menor quantidade ácido olêico e sabões. Em cadáveres com panículo adiposo farto esse fenômeno é mais comum.

Mumificação. Se, ao contrário, tivermos um cadáver de indivíduo magro, em ambiente seco, bem ventilado e quente, a sua dessecação será tão-intensa, que por falta de condições apropriadas, as bactérias não poderão sobreviver e secando completamente, o corpo se mumificará. A mumificação pode ser produzida de forma natural ou artificial. Nas mumificações artificiais, os corpos são submetidos a processos especiais de conservação e tais artifícios datam da mais remota época, através dos embalsamamentos. Na mumificação natural são necessárias condições particulares que garantem a desidratação rápida, de modo a impedir a ação 
microbiana responsável pela putrefação. O cadáver mumificado apresenta reduzido em peso, pele dura, seca, enrugada e de tonalidade enegrecida. Os dentes e as unhas permanecem bem conservados. Já a cabeça fica diminuída de volume.

Calcificação. Caracteriza-se pela petrificação ou calcificação do corpo. Ocorre mais freqüentemente nos fetos mortos e retidos na cavidade uterina.

8. Morte Rápida ou Súbita e Morte Lenta.

A velocidade de instalação e ultimação do processo de morte poderá ser útil para criar uma subdivisão que é usada pelos médicos legistas. Denomina-se morte súbita aquela que, pela brevidade de instalação do processodesde segundos até horas-, não possibilita que seja realizada uma pesquisa profunda e uma observação apurada da sintomatologia clínica, hábil a ensejar um diagnóstico com certeza e segurança. O conceito mais aceito de morte súbita se deve a Vibert: "compreendem-se, em Medicina Legal, sob o nome de morte súbita, os casos onde a morte sobrevem mais ou menos rapidamente, em alguns segundos, algumas horas, ou mesmo dias, mas de modo imprevisto, atingido, sem causa aparente um indivíduo até então de boa saúde ou que não apresentava se não ligeiros distúrbios ou que, pelo menos, assim parecia às pessoas que o circundavam"

O professor doutor Marcos de Almeida, em sua tese de doutoramento, apresentada e defendida na Escola Paulista de Medicina: Importância médico legal da drepanocitose na morte súbita, pesquisou casos de drepanocitose, também conhecida como anemia falciforme ou estigma falciforme, ocorridas em mortes súbitas (chamadas de necrópsia branca). Este defeito morfológico é mais comumente observado em indivíduos de raça negra que sofrem de anemia. Posteriormente, foi caracterizada como uma deficiência geneticamente determinada e ligada ao conteúdo hemoglobínico das hemácias. Em nosso país, foram encontrados, numa amostragem de mais de novecentos casos, dezenove pessoas que faleceram subitamente em conseqüência dessa deficiência, sendo possível, segundo o autor a atuação nos casos de acidente de trabalho. 
O termo morte súbita tem uma dupla conotação:

1. objetiva, a rapidez com o que ocorre o óbito.

2. subjetiva, caráter inesperado com que se dá o decesso.

Recebe o nome de morte lenta ou agônica aquela que, em geral, vem de maneira esperada, devagar, significando a culminação de um estado mórbido, isto é, de uma doença ou da evolução de um traumatismo.

9. Morte natural.

É aquela que sobrevem como consequiência de um processo esperado e previsível. Por exemplo, nos casos de envelhecimento natural, com esgotamento progressivo das funções orgânicas. Em outros casos, o óbito é um corolário de uma doença interna, aguda ou crônica, a qual pode ter acontecido e transcorrido sem intervenção ou uso de qualquer fator externo ou exógeno. É evidente que strictu senso, a causa do óbito não é "natural" e, sim, patológica. Todavia, habitual do termo considera o tipo de morte como natural.

10. Morte violenta.

Um dos objetivos primordiais do estudo da Tanatologia médico legal é estabelecer o diagnóstico da causa jurídica de morte na busca de determinar as hipóteses de homicídio, suicídio ou acidente. A violência do latim violentia e vis, força, é um fenômeno no qual interveio a força externa como causa desencadeante.

Cada uma destas mortes que se atribuem a homicídio, suicídio ou acidentes apresenta particularidades, embora, por vezes, seja difícil estabelecer diferença precisa entre formas próximas. As características das lesões nem sempre permitem distinção clara entre as diferentes naturezas jurídicas. São incontáveis as situações em que pode ocorrer morte acidental. Por exemplo, acidentes de tráfego, acidentes domésticos. Quanto ao homicídio, o Código Penal trata da matéria no art. 121 (matar alguém). Homicídio, do latim hominis excidium, é definido com Carmignani como "morte injusta de um homem, praticada por outro, direta ou indiretamente" Mas também cogita de casos em que o evento ocorre em consequiência de outro delito que o precede: art. 127 (se do aborto resulta a morte da gestante); art. $129, \S 3^{\circ}$ (se da ofensa à integridade resulta a morte); art. $133, \S 2^{\circ}$ (se 
do abandono de incapaz lhe resulta a morte); art. 134, $\S 2^{\circ}$ (se do abandono de recém-nascido lhe resulta a morte); art. 135 (se de omissão de socorros resulta a morte), etc. Da perícia médico-legal muito se espera para o estabelecimento da natureza jurídica do fato.

Morte voluntária (suicídio). "Chama-se suicídio todo caso de morte que resulta, direta ou indiretamente de um ato positivo ou negativo, realizado pela própria vítima, a qual sabia dever produzir este resultado" (Durkheim). As causas são inúmeras. Segundo Bonnet podem ser exógenas (socioambientais) e endógenas (biopsíquicas). Na velha Roma punia-se o suicídio do soldado, pelo prejuízo causado ao Estado. Punia-se, também o do réu e o do escravo, pelo prejuízo patrimonial. A pena se consubstanciava na mutilação do cadáver. O Código Penal brasileiro vigente, pune apenas o induzimento, instigação e o auxílio ao suicídio no art. 122 .

\section{Morte Suspeita.}

Rotula-se como morte suspeita aquela que, mesmo çom testemunhas, e com alguns dados de orientação diagnóstica, se mostra duvidosa quanto à sua origem. Sua freqüência é bastante elevada. Segundo Armando Canger Rodrigues, de acordo com estatística realizada na cidade de S. Paulo, foi observada uma incidência de $12 \%$ de mortes de causa indeterminada.

\section{Morte sem Assistência.}

As maiores dúvidas que suscitam este tipo de óbito se relacionam com o fato de ocorrer sem testemunhas, em locais isolados ou em pessoas que moram sozinhas e que, tampouco procuram auxílio. Os SVO, Serviços de Verificação de Óbito são instituições que têm por finalidade a determinação da realidade da morte, bem como a sua causa - desde que natural e não-externa - nos casos de óbitos ocorridos sem assistência médica ou com assistência médica, mas em que este sobreveio por moléstia maldefinida. Lei n. 5452, de 22.12.86 reorganizou esses serviços. Ver também os arts. 15, 72, 114 do Código de Ética Médica, Resolução CFM n. 1.246, de 8.1.68. 


\section{Diagnóstico da Morte}

Vimos que o diagnóstico da morte no ser humano tem variado ao longo do tempo. Assim é que depois do estabelecimento sucessivo da putrefação, do estado de rigidez e do resfriamento cadavérico, bem como da cessação da respiração como sinais primários da tanatognose, passou-se a encarar o coração como órgão principal da vida e sua parada como indicação definitiva de morte. Com o desenvolvimento de meios mecânicos extraordinários, artificiais, substitutivos da díade funcional coração-pulmão, para a manutenção da atividade cardiorrespiratória, e a possibilidade de reanimar um coração parado através de massagens, drogas cardiotônicas e estímulos elétricos, a parada cardíaca teve sua posição fortemente abalada. Tal fato não chegara a suceder com a revelação feita por Brouardel, no fim do século passado de que o coração de decapitados, desde que tomadas certas medidas, continuava a bater por períodos que podiam atingir até uma hora. Culpa, talvez, da precariedade dos meios de divulgação da época.

As coisas caminhavam de modo aparentemente sereno, sem maiores disputas conceituais, quando o transplante de coração realizado por Christian Barnard, na África do Sul, em fins de 1967, precipitou de maneira inevitável os acontecimentos. Denise Ann Darvall, tinha 25 anos quando por um acidente de trânsito teve seu crânio e cérebro quase que totalmente esmagados. Seu coração foi retirado e transplantado no comerciante Louis Washkansky. Após dezoito dias o comerciante também faleceu. "E o fato, já aceito pela classe médica, da precedência em nível de importância funcional do encéfalo sobre o coração, teve que ser trazido à baila. Essa verdade inconteste seria cedo ou tarde inevitavelmente incorporada de forma progressiva e natural, pela população, não fosse o modo brusco e inopinado como foi posta em cena. É traço instintivo da natureza humana a resistência a qualquer tentativa de modificação rápida das idéias estabelecidas e conceitos estratificados por longo período de tempo. E isto é particularmente notável nas formulações de caráter médico que transcendem as fronteiras da própria medicina e entram nas cogilações de todos os grupos humanos." (Marco Segre, op. cit., p. 236).

Alega-se que os parâmetros éticos atuais mantêm a função cardiorrespiratória como o elemento capital na determinação da morte. Isso, todavia, não-implica considerá-los como definitivos e acima de qualquer discussão. Como mencionamos vários fenômenos funcionaram como sinais eleitos de morte em outras épocas, a Medicina Legal, mesmo, rejeitava a morte se não se instalassem os 
processos de putrefação ou rigidez cadavérica. Tais questões levam, não-só os médicos como os juristas ao reexame da conceituação da morte, já que a ausência das funções cerebrais não impedem que sejam mantidas artificialmente as funções da respiração e de circulação, o que os fisiologistas denominam vida técnica. A chamada brain death exsurgiu pari passu com o advento dos transplantes de órgãos e tecidos humanos. Os avanços tecnológicos da medicina propiciaram prolongar indefinidamente uma vida, por intermédio da circulação extracorpórea e respiradores artificiais, possibilitando ainda, a ressuscitação cardíaca e modificando o conceito de morte clínica. A realização de transplantes exige órgãos íntegros, viáveis, hígidos e perfundidos; o que ensejou os mais variados debates sobre o assunto, na busca de uniformização de conceitos.

Em 1959, Mollaret e Gaulon utilizaram o termo "coma dépassé" para descrever o coma vegetativo. Coma é uma síndrome caracterizada, clinicamente, por perda mais ou menos completa da consciência, da motricidade voluntária e da sensibilidade, com conservação das funções vegetativas intactas ou modificadas. Trata-se de situação de urgência e de extrema gravidade, traduzindo sempre profundo sofrimento de estruturas encefálicas.

De acordo com as alterações do estado de consciência e das funções vegetativas, assim como da reatividade elétrica obtida aos estímulos, os comas são classificados em graus de intensidade.

Grau I- Obnubilação, coma vigil, torpor ou semicoma. Neste tipo há apenas uma depressão da consciência, persistindo algum contato com o meio.

Grau II- Coma superficial. Neste grau o comprometimento da consciência se acentua, interrompendo-se as conexões do paciente com o meio. As funções vegetativas permanecem inalteradas.

Grau III- Coma profundo ou "coma carus" Neste grau há abolição completa da consciência e de toda conexão com o meio. O paciente não reage a estímulos, qualquer que seja sua intensidade.

Grau IV- Coma dépassé. O grau III nas antigas classificações correspondia as formas mais avançadas de coma. Recentemente, em consequiencia das novas técnicas de reanimação observam-se estados que ultrapassam esse estágio. Neste grau o eletroencefalograma revela silêncio elétrico. Trata-se de coma geralmente irreversível. 
Definições Hipotéticas de Morte:

Vimos que a denominada morte clínica não-coincide com a morte biológica, mas necessariamente, a precede. Ferrando Mantovani (I trapianti e la sperimentazione umana, p. 353), para evitar equívocos, propõe uma distinção preliminar: 1. a morte do organismo humano inteiro em todos os seus componentes, chamada morte biológica e 2. a morte do indivíduo humano representada pela morte clínica. Esta última intimamente relacionada com o conceito de pessoa (persona) não leva em consideração as manifestações biológicas da sobrevida.

a. morte cortical é entendida quando é irrecuperável a atividade cerebral superior isto é, aquela do centro cortical e subcortical que condiciona a vida intelectiva e é a sede da vida sensitiva. Possibilita as relações, valores e significados sociais, embora resultem conservadas as funções vegetativas e, em particular, a função cardiorrespiratória. Tais lesões cerebrais permitem ao indivíduo sobreviver, porém, em condições puramente vegetativas, ou, nos dizeres de Marcozi "como um cadáver vivente", porque privado das funções especificamente humanas.

b. morte cerebral ou descerebração ocorre quando irreversivelmente cessa a atividade do sistema nervoso central. Caracteriza-se pela cessação total das atividades cerebrais, atingindo a estrutura encefálica, hoje caracterizada como morte encefálica. As imprecisões conceituais entre morte cerebral e morte encefálica tem gerado inúmeras dúvidas. É imperioso distingui-las.

c. morte cardíaca a opinião minoritária é a de que há morte só quando cessam irreversivelmente não-só a atividade encefálica, mas também a cardiorrespiratória, isto é, quando não possam mais ser mantidas, nem com o auxílio de meios artificiais.

\section{Morte Encefálica:}

Em 1968, quando o Comitê ad hoc de Harvard foi requisitado para dar uma definição de Coma Irreversível, o referido Comitê afirmou que só poderia definir um status de vida, por ser o coma uma espécie de vida, ainda que mínima. "Ser uma pessoa" não termina pelo processo de morrer. A personalidade do homem está inseparavelmente conectada a sua unidade. Brain Death apenas marca um decisivo ponto durante o processo de morrer e não pode ser definido como a morte do ser humano "em geral" As objeções ao novo dualismo do encéfalo e corpo como 
também as do corpo e personalidade "alma" são muitas. A questão se refere ao problema de sobrevivêncià de pacientes em cuidados intensivos e sem nenhuma possibilidade de recuperação. Os cuidados intensivos são anti-econômicos, não apenas do ponto de vista técnico, mas também sob o ponto de vista humano. $\mathrm{O}$ Comitê elaborou critérios de avaliação de morte encefálica citando o Papa Pio XII que, em 1958, disse que o processo de morrer deveria ter um tempo no qual uma vez ultrapassado os médicos deveriam parar de lutar contra a morte e poderiam deixá-lo morrer.

Critério de Harvard, 1968 - Tabela 1:

- Coma arresponsivo, temperatura maior que $32^{\circ}$

- Ausência de drogas depressoras

- Ausência de movimentos espontâneos

- Apnéia da V.M. por 3 minutos aa

- Arreflexia incluindo:

Ausência de corticação ou descerebração

Pupilas fixas e dilatadas

Ausência de vocalização

Ausência de reflexos faríngeos e corneanos

Ausência de reflexos tendinosos profundos

EEG isoelétrico

- Todos deveriam estar presentes por 24 horas

Estes critérios são muito específicos. Apenas $4,1 \%$ dos pacientes que evoluíram para óbito preenchiam os critérios. A repetição da avaliação após alguns dias diagnosticou em 20,2\% dos casos. Reflexos medulares podem ocorrer em $50 \%$ dos pacientes com morte encefálica, não invalidando o diagnóstico. Freqüentemente aparecem após as primeiras 24 horas do diagnóstico clínico.

Até hoje não existem claras regras para definir que espécie de vida está ou não o médico obrigado a deixar morrer, ou seja, não temos regras de uma definição unanimemente aceita. A dificuldade em encontrarmos regras ou definições para esses pacientes dependem das técnicas possíveis de um lado e, de outro, das chances de ressuscitação de uma vida aceitável que nos sirva de guia. O Comitê de Harvard conhecia bem esta dificuldade e procurou encontrar para ela uma solução. Finalmente, sem nenhuma dúvida, não existe possibilidade de recuperação quando o 
encéfalo está morto. Para responder a questão, quando a morte encefálica é ainda uma espécie de coma ou não, isto significa que uma espécie de vida, ou não, não é mais necessária. Então, o Comitê preferiu responder a questão de quando o médico pode e precisa encerrar o tratamento, mas isto não é suficiente. Para uma resposta inequívoca, a questão continua aberta, porque a cessação da ressuscitação normalmente ocorre antes da morte encefálica. Complicações legais segundo o Comitê podem ocorrer na declaração do óbito se definimos este status. Então, a questionada definição de coma irreversível pode ser uma definição de morte? Quando o encéfalo está morto, é possível retirar órgãos desse paciente. Este é o segundo efeito desta definição. Mais tarde, a nova definição de morte recebeu uma base mais filosófica por outros povos. Isto é o que chamamos de conceito antropológico. É o término da consciência e da habilidade de se comunicar e raciocinar, que são essenciais ao homem em relação aos demais animais. As conseqüências dessa filosofia são: primeiro, quando o término dessas essências humanas significam o fim da vida humana, quando o começo dessas essências não são localizadas, teríamos o começo da vida humana? Segundo, a morte encefálica parcial é também considerada como a morte do ser humano? O campo para os valores individuais está aberto. Por estas razões, o conceito de morte encefálica para a morte do homem inclui perigosas conseqüências. Por exemplo, os bebês com anencefalia não pertencem mais à comunidade do homem. Não há mais alguém, mas apenas alguma coisa. Não obstante, o conceito de morte encefálica é aceito mundialmente. A razão para isso é que existem erros conceituais da "brain death" pelo Comitê de Harvard. A morte encefálica não pode ser mais um conceito antropológico, mas precisa ser um conceito biológico. Isto significa que o ser humano apenas por um motivo biológico tem um ponto terminal. Por isso, a morte encefálica é um seguro sinal de morte do organismo e, concorrentemente a morte do homem. Convém lembrar a distinção: brain significando encéfalo e, córtex significando cérebro. É comum o erro na tradução.

Critérios do Royal College, 1976, Inglaterra Tabela 2:

Observamos serem dispensáveis os exames subsidiários na presença de:

- ausência de reflexos medulares

- pupilares

- corneanos 
- óculovestibular

- tosse

Apnéia com retirada da V.M.

Reflexos podem estar positivos

Repetir testes após observação

EEG e estudos do fluxo sangüíneo não necessitam serem confirmados por mais dois colegas.

Pré-requisitos:

coma profundo

temperatura maior que $35^{\circ}$

Destrutural do SNC (não-metabólica)

Lancet 1976 2: 1069

USA - Comissão Presidencial para o Estudo dos Problemas Éticos em Medicina e Pesquisa Biomédica e Comportamental-para adultos e crianças maiores de cinco anos Tabela 3:

Task Force 1987

- Coma e apnéia devem existir

- Ausência de atividade do tronco cerebral

- Pupilas médio fixas ou midriáticas sem rfm.

- Ausência de movimentos oculares espontâneos

- Ausência de movimentos oculares induzidos

- Oculocefálico (Doll'eyes) e óculovestibular (P calórica)

- Ausência de movimentos musculares bulbares incluindo faciais e orofaríngeos

- Movimentos respiratórios ausentes fora da V.M. (Teste da Apnéia)

- Não deve haver hipotermia e hipotensão

- Tônus flácido com ausência de movimentos espontâneos ou induzidos, excluindo os reflexos medulares

- Este exame deve ser mantido e consistente com ME em todo o período de teste

- O período de observação varia com a idade 
Pediatrics 1987 80:298

Em 1987, um Grupo Tarefa Especial, baseando-se nas normas da Comissão Presidencial, estabelece normas para serem aplicadas em crianças menores. Atualmente, a maioria dos protocolos sobre morte encefálica, são baseados nessas recomendações. Como podemos observar nas tabelas 3 e 4 , é utilizado o exame neurológico completo, associado ou não a exames subsidiários, dependendo da faixa etária em estudo. O tempo de observação também é variável, sendo maior nos lactentes e recém-nascidos e após quadros de hipóxia acentuados. Até o momento, não existe consenso na literatura a respeito dos critérios a serem utilizados em recém-nascidos com menos de sete dias.

Tabela 4: Morte encefálica, Task Force

idade

avaliação

período de observação

7 dias a 2 meses

2 exames clínicos

48 horas

$2 \mathrm{EEG}$

2 meses a 1 ano

2 exames clínicos

24 horas

2 EEG

Não é necessário o segundo EEG se for disponível uma arteriografia cerebral com radionuc.

Maior de um ano

2 exames clínicos

12 horas

s/exame subsidiário

Se encefalopatia hipóxica

24 horas

ISQ

O período pode ser reduzido se o EEG ISQ ou angiografia com radionucleotídeos: sem fluxo.

Na Alemanha o "Bundesärztekammer" durante muitos anos aceitou o conceito de morte encefálica como morte do homem e publicou regras de trabalho com este conceito; agora, aceita o conceito biológico ao invés do conceito antropológico de morte encefálica para a morte do homem. A Itália identifica a morte encefálica como a morte do homem.

A questão de quando a pessoa morre é agora reduzida à questão, quando o organismo do homem morre, e a resposta é simples: quando morre todo o encéfalo. Restam ainda duas dificuldades. Primeiro, se pudermos restabelecer a 
função do encéfalo por alguma forma de prótese ou transplante, poderá a vida do organismo então continuar? Temos que responder não, porque esta essencial função biológica do organismo virá de fora desse organismo. A espontaneidade precisa ser autônoma, bem como a comunicação, controle e a integração. Segundo, a morte humana ocorrida sob condições de cuidados intensivos parece ser a vida. A morte é visível e não mais pode ser uma experiência direta, mas apenas técnica e com o auxílio de especialistas. Este é o preço que temos de pagar quando abandonamos o caminho da natureza ("Shizen" em japonês). Com a esperança de uma vida melhor em um mundo parcialmente artificial.

Desde que Mollaret e Goullon examinaram a questão em 1959, denominando de "coma dépassé" esta singular situação de um "cérebro morto em um corpo vivo" muitos têm tentado demonstrar de maneira objetiva a morte encefálica. Os critérios em uso atualmente são basicamente parecidos, diferindo fundamentalmente no tempo de observação e na necessidade ou não de exames comprobatórios. Quaisquer que sejam os critérios, existem dois pontos básicos indispensáveis: 1. a causa da lesão encefálica deve ser necessariamente conhecida, quer por lesão estrutural, quer metabólica; 2. as estruturas vitais do encéfalo, necessárias para manter a consciência e a vida vegetativa, estão lesadas irreversivelmente.

No Brasil, o conceito de morte encefálica foi feito por ocasião do primeiro transplante a partir de cadáver em 26 de maio de 1968, quando Euríclides de Jesus Zerbini trocou o coração do boiadeiro João Ferreira da Cunha por outro sadio de Luís Ferreira Barros, vítima de acidente de trânsito. João Ferreira morreu em 22 de junho de 1968. A pedido dos Professores Zerbini, Campos Freire e Paulo Vaz de Arruda foi estabelecido no Hospital das Clínicas da FMUSP, o conceito e comprovação de morte real, calcado somente em critérios eletroencefalográficos. $\mathrm{O}$ conceito é baseado na constatação clínica de coma aperceptivo e ausência de reflexos ou movimentos supraespinais, excluídos hipotermia e depressão medicamentosa, com a observação mínima de seis horas. O achado clínico deverá necessariamente ser respaldado por um exame subsidiário que demonstre inequivocamente ausência de atividade elétrica cerebral, ou ausência de perfusão sangüínea cerebral ou de atividade metabólica. O cérebro pode ser deprimido por drogas até níveis afuncionais, não perdendo entretanto a capacidade de recuperação, como por exemplo em anestesia geral. Em diversos centros neurotraumatológicos se usam rotineiramente doses elevadas de barbitúricos, como medida de proteção 
cerebral, e o paciente nestas condições se apresenta arreativo e com traçado eletroencefalográfico isoelétrico. Acredita-se que a hipotermia reproduza este quadro. Abundante experiência clínica e laboratorial demonstra que um cérebro sem estar sob o efeito de drogas depressoras e que mostre ausência de função por um período de poucos minutos, após uma agressão estrutural ou metabólica, não tem chances de melhorar. Nos diversos critérios existentes, entretanto, o período de observação varia de 6 a 24 horas. A grande maioria dos critérios excluem as crianças, não havendo ainda um consenso no diagnóstico e na confirmação da morte encefálica.

O exame da atividade do tronco encefálico na morte encefálica em crianças de mais de três anos de idade e adultos compreende os seguintes achados:

1. Pupilas Paralíticas - devem estar fixas e arreativas frente a um estímulo luminoso;

2. Arreatividade Supra-Medular;

3. Ausência do Reflexo Córneo Palpebral;

4. Ausência de Reflexos Óculo Vestibulares - pesquisando pela movimentação lateral ou vertical da cabeça ou então pela irrigação dos condutos auditivos com $50 \mathrm{~cm}$ de água gelada:

5. Apnéia - é o exame mais importante. Deve-se lembrar que a maioria dos pacientes comatosos encontram-se em hipocapnia e hiperoxigenados. Por isso deve-se realizar a prova da Apnéia de acordo com o seguinte protocolo:

- ventilar o paciente com $\mathrm{FO}_{2}$ de $100 \%$

- desconectar o ventilador

- instalação de cateter traqueal de oxigênio com fluxo de 6 litros/minuto

- observar os movimentos respiratórios por 10 minutos, visto que a cada minuto de apnéia a $\mathrm{PaCO}_{2}$ aumenta de $3 \mathrm{mmHg}$, portanto após 10 minutos teremos uma ascensão da $\mathrm{PaCO}_{2}$ em $30 \mathrm{mg}$.

As falhas diagnóstico-clínicas se associam a doenças prévias, drogas anticolinérgicas e bloqueadores neuromusculares.

Os exames subsidiários que confirmam o diagnóstico clínico da morte encefálica são vários. A ausência de atividade elétrica é evidenciada pelo EEG e pelo estudo dos potenciais evocados. A ausência de perfusão sangüínea cerebral é evidenciada pela arteriografia, pelo estudo radioisotópico, pelos estudos ultrasonográficos transcranianos e pela monotorização da pressão intracraniana. A 
ausência de atividade metabólica é evidenciada pelo Pet Scan e por métodos que medem a extração e consumo de oxigênio.

A preocupação recente em caracterizar a morte encefálica como morte clínica, segundo o doutor Luis Alcides Manreza, diretor técnico do serviço de saúde

Serviço de Neurologia do Hospital das Clínicas e membro da Comissão de Transplante de Órgãos, "relaciona-se com os pacientes que se tornaram inviáveis nos leitos de terapia intensiva e aos programas de transplantes de órgãos. Um progresso da legislação se iniciou em 3/3/1988, quando o Congresso deteminou ser da competência do Conselho Federal de Medicina todo ato médico. Em 1990 o CFM determinou que a morte encefálica tem o valor de morte clínica"

Em 8 de agosto de 1991 o Conselho Federal de Medicina editou a Resolução n. 1.346 (em anexo).

Avaliando a resolução, alguns pontos merecem maior reflexão:

1. a referida resolução foi elaborada em 1991 e desde então vários anos se passaram;

2. o CFM considera que não existe consenso sobre a aplicabilidade em crianças menores de dois anos;

3. o diagnóstico de morte encefálica é clínico, através do exame neurológico completo, sendo ressaltada a utilização do Teste da Apnéia;

4. foram excluídos dos critérios os casos de intoxicação metabólica, intoxicação por drogas ou hiportemia, consoante literatura a respeito;

5. o período de observação clínica para a confirmação do diagnóstico de morte de pelo menos seis horas é muito restrito (deveria ser, no mínimo 12 horas);

6. é obrigatória a utilização de um exame complementar para confirmação diagnóstica, podendo ser o eletroencefalograma ou um estudo de perfusão encefálica;

7 após confirmado o diagnóstico de morte encefálica, o fato deverá ser comunicado aos responsáveis legais, antes de se adotar qualquer medida adicional. O diagnóstico de morte encefálica encontra respaldo legal em nosso país, na atual Lei de Transplante de Órgãos n. 9.434, de 4 de fevereiro de 1997, que dispôs em seu art. $3^{\circ}$ : 
Art. $3^{\circ}$ A retirada post-mortem de tecidos, órgãos ou partes do corpo humano destinados a transplantes ou tratamento deverá ser precedida de diagnóstico de morte encefálica, constatada e registrada por dois médicos não-participantes das equipes de remoção $e$ transplante, mediante a utilização de critérios clínicos e. tecnológicos definidos por resolução do Conselho Federal de Medicina"

E, em seu art. $7^{\circ}$, parágrafo único estabelece:

"Parágrafo único No caso de morte sem assistência médica, de óbito em decorrência de causa maldefinida ou de outras situações nas quais houver indicação de verificação da causa médica da morte, a remoção de tecidos, órgãos ou partes de cadáver para fins de transplante ou terapêutica, somente poderá ser realizada após a autorização do patologista do Serviço de Verificação de Óbito responsável pela investigação e citada em relatório de necrópsia"

O problema da morte encefálica é sobretudo um problema de ordem prática --- diagnóstico que resguarda uma possibilidade científica de acertamento. $\mathrm{O}$ primeiro problema a ser focalizado é o da caracterização do silêncio cerebral, distinguindo-o de outros aspectos com que pode ser confundido:

a. o traçado achatado;

b. o traçado deprimido.

Particularidades da distinção:

a. silêncio elétrico ou traçado nulo --- esta particularidade se caracteriza pela abolição total da atividade cerebral, manifestada pela presença de uma linha isoelétrica, mesmo utilizando-se a amplificação máxima, somente interrompida pela eventual intercorrência de artefatos;

b. traçado deprimido --- esta particularidade é caracterizada por potenciais lentos, de muito baixa voltagem, chegando mesmo a se limitar, por vezes, a pequenas oscilações da linha de base. É um caso inteiramente patológico, que tem sido confundido com o silêncio cerebral. 
O segundo problema é que o silêncio elétrico pode se apresentar de duas maneiras, a saber: contínua ou descontínua. O silêncio difuso contínuo merece especial atenção, uma vez que de sua identificação podem ser deduzidas conclusões pertinentes ao prognóstico para se estabelecer a distinção entre a morte real e a aparente. Adotamos aqui os parâmetros propostos por Schneider referentes à caracterização do tempo de sobrevida, do tempo de latência de recuperação, do tempo de recuperação e, finalmente, do tempo de reanimação. Em conclusão, a linha isoelétrica, como expressão da morte cortical, deve ser caracterizada por um silêncio elétrico cerebral global e contínuo, com a duração mínima de dez minutos, salvo se o paciente estiver sob a ação hipotérmica induzida.

Outros aspectos a serem considerados:

- Não podemos nos esquecer que o entendimento do conceito de morte varia segundo a cultura e o momento histórico, e que existe sempre uma valoração crítica das idéias, atitudes e mitos em torno do simbolismo da morte.

Os condicionamentos no momento atual impostos pela sociedade e nossa cultura na forma de sentirmos, vivenciarmos e conceituarmos a morte estão

Subordinados aos seguintes marcos de referência:

- a valorização das mortes rápidas, instantâneas, indolores, acidentais.

- o deslocamento progressivo do fenômeno da morte do domicílio para o hospital (aproximadamente só de 25 a 30\% ocorrem no domicílio familiar).

- as mudanças na forma de viver o luto e as cerimônias fúnebres.

- a substituição de conceitos tradicionais por causa dos avanços técnicos.

- os pacientes terminais e o conceito de futilidade terapêutica.

- eutanásia.

- transplante de órgãos.

\section{Legislação Aplicável}

- O Código Civil vigente, em seu art. 10 define que a existência da pessoa natural se extingue com a morte. $\mathrm{O}$ artigo seguinte estabelece a comoriência, prescrevendo que se dois ou mais indivíduos falecerem na mesma ocasião, não se podendo averiguar se alguns dos comorientes precedeu aos outros, presumir-seão simultaneamente mortos. $\mathrm{O}$ art. 315 estabelece que a sociedade conjugal 
termina pela morte de um dos cônjuges. No seu parágrafo único, o casamento válido somente se dissolve pela morte de um dos cônjuges ou pelo divórcio. $\mathrm{O}$ art. 392 do mesmo dispositivo legal, prevê a extinção do pátrio poder pela morte dos pais ou do filho.

- Também o Código Penal prevê, no art. 107 a extinção da punibilidade pela morte do agente. $\mathrm{O}$ art. 121 fala "Matar a alguém: Pena: reclusão de seis a vinte anos" $\mathrm{O}$ art. 122 pune o induzimento, instigação e auxílio ao suicídio. $\mathrm{O}$ art. 210, em violar ou profanar sepultura ou urna funerária; o art. 211, em destruir, subtrair ou ocultar cadáver ou parte dele; o art. 212, em vilipendiar cadáver ou suas cinzas, todos punidos com reclusão de um a três anos e multa. A Lei de Contravenções Penais, no art. 67 pune quem inumar, ou exumar cadáver, com infração das disposições legais.

- O Código de Processo Penal, em seu art. 162, prevê "que a autópsia será feita pelo menos seis horas depois do óbito, salvo se os peritos, pela evidência dos sinais de morte, julgarem que possa ser feita antes daquele prazo, o que declararão no auto" Parágrafo único: nos casos de morte violenta, bastará o simples exame externo do cadáver, quando não houver infração penal que apurar, ou quando as lesões externas permitirem precisar a causa da morte, e não houver necessidade de exame interno para verificação de alguma circunstância relevante. Os arts. 158, 159, 161, 163, 164, 165, 167, 170, 182, também estão relacionados com o conceito de morte.

Devem ser considerados ainda os seguintes dispositivos legais: Lei de Acidente do Trabalho, n. 8.213, de 24 de julho de 1991, art. 74, que fala na pensão por morte, o art. 75, que estabelece o valor desta pensão por morte, e o 81 , que estabelece os pecúlios; o Código Nacional de Saúde, Decreto n. 49.974-A, de 21 de janeiro de 1961, art. 13; o Serviço de Verificação de Óbito, Decreto n. 51.014, de 5 de dezembro de 1968 , arts. $2^{\circ}$ e $3^{\circ}$; a Lei sobre Cremação de Cadáver n. 6216, de 30 de junho de 1975, art. 77; o Provimento 13/80, de 21 de maio de 1980, da Corregedoria Geral de Justiça, a atual Lei de Transplante de Órgãos, de 2 de fevereiro de 1987 e a sua regulamentação, entre outros. 
Conclusões.

Os argumentos apresentados buscando um novo paradigma na conceituação médico-forense de morte, como vimos, são confundidos com a sua verificação, diagnóstico e, até mesmo, seu prognóstico.

Se não sabemos o que é a morte, como então conceituá-la?

Vivemos hoje mais da metade da chamada "Década do Cérebro" Em 25 de junho de 1989, o então presidente, George Bush assinou decreto que, transformado em lei pelo Congresso dos Estados Unidos, consignou a presente década, a partir de 1990, como década do cérebro. Desta forma, as pesquisas em neurociências se tornaram prioridade nacional e internacional.

Uma bateria de novos recursos-diagnósticos, como a tomografia computadorizada, a ressonância magnética, a magnetoencefalografia, a tomografia por emissão de pósitrons (pet-scanner), a radiocirurgia estereotáxica, a neuronavegação, etc., têm tornado a neurocirurgia verdadeira ciência do futuro.

A morte encefálica é, segundo o American Society of Neuroradiology (AJMR 17: 731-735, abril de 1997):

"O estado irreversível de cessação de todo o encéfalo e funções neurais, resultante de edema $e$ maciça destruição dos tecidos encefálicos, apesar da atividade cardiopulmonar poder ser mantida por avançados sistemas de suporte vital e mecanismos de ventilação"

'A ausência de fluxo sangüíneo encefálico é geralmente aceita como signo da morte encefálica. $A$ razão desse signo é, porém, incerta. Uma pressão intracraniana alta não a única explicação para a ausência de perfusão cerebral. Estudos vasculares cerebrais com angiografia por contraste SPECT tem sido usados para a confirmação e documentação do diagnóstico clínico" 
Modernamente, a angiografia por ressonância magnética mostrou ser um método mais preciso, não-invasivo e de mais alta resolução (Turski P, "Magnetic Resonance Angiography: Central Nervous System Applications", 1994).

Novos conhecimentos sobre o metabolismo das células nervosas têm aberto caminho para a prevenção, a cura ou o alívio de muitas doenças neurológicas; algumas delas, já claramente vistas em imagens a cores na tela do Pet-Scanner, um tomógrafo que permite ver "a função" da área do cérebro através do metabolismo da glicose radioativa, injetada no paciente.

Os transplantes de tecidos heterólogos ou fetais para o cérebro humano já são uma realidade.

Conforme anunciado pelo psicólogo inglês Jeffrey Gray, chefe do Departamento de Psicologia da Universidade de Londres, em conferência feita na USP: em 8.9.97, é possível que "migrações de células possam tratar danos no cérebro" Baseando-se em experiências com ratos, o pesquisador conseguiu fazer com que células primordiais (retiradas de fetos de ratos) migrassem exatamente para os lugares nos quais eram necessárias. Ou seja, depois de implantadas em cérebros, propositalmente danificados, elas seguiam para os locais lesados e passavam a trabalhar como se tivessem sido programadas para atuar naquela área, suprindo a falta das células perdidas.

A conquista mostra a possibilidade de se utilizar células fetais ainda não-diferenciadas (isto é, sem endereço certo) em transplantes para a recuperação de funções cerebrais perdidas. A técnica atenuaria o problema ético de se usar células de fetos em idade gestacional avançada. Os neurônios humanos que atuam no hipocampo (região cerebral envolvida na memorização e no processamento de emoções), por exemplo, só ficam prontos para atuar especificamente por volta dos seis meses de gestação. Em um transplante de neurônios humanos, as células utilizadas seriam retiradas de fetos, vítimas de abortos espontâneos, mais freqüentes até os três meses.

Fazer com que células primordiais migrem para as regiões cerebrais onde seriam necessárias, é uma ótima notícia. Vislumbramos através destas novas técnicas a neurologia do futuro, em que células embrionárias poderão substituir células doentes. Trata-se de linha de pesquisa que vem ganhando importância muito rapidamente e que virá, em futuro próximo, revolucionar o atual conceito médicoforense de morte encefálica. 
O problema fundamental que o tema propõe e que não é suscetível de solução pelos juristas é o da definição da morte. Eram as seguintes as palavras do professor Paulo Vaz de Arruda a este respeito, quando da elaboração da Lei de Transplantes anterior:

"Verificar, constatar a morte dos outros é algo profundamente angustiante. Na filosofia da ciência, já está estabelecido que o que é mais valioso é a hipótese, desde que seja uma hipótese de boa qualidade. A hipótese é mais importante que a própria conclusão, pois uma vez chegada à conclusão, não se tem nada mais em disponibilidade; é tão verdadeira a relatividade e a mutabilidade dos conceitos científicos que os encarregados da reformulação procuram dar um conceito vasto e mais amplo do problema da vida real e da vida aparente. Embora seja profundamente angustiante verificar e constatar a morte dos outros, estamos acostumados a fazê-lo. E tudo isto tem sentido, porque existe a perspectiva de uma nova vida real"

Não cabe à Lei, porque lhe seria impossível, definir ou determinar quando se deu a morte. Caberá aos médicos, à Ciência estabelecer os critérios para quando se considere tenha aquela ocorrido. Nesta seara o Direito só pode intervir para exigir segurança quanto à realização do ato em determinados estabelecimentos, sempre porém, a última palavra caberá à Medicina, à decisão do facultativo e de sua consciência.

O conceito médico-forense de morte é um conceito dinâmico, aberto $e$ funcional; por isso permite que sejam mudados, no tempo e no espaço, os critérios e indicadores de sua constatação e não propriamente o seu conceito.

São Paulo, novembro de 1997. 
Bibliografia.

AD HOC COMITEE OF HARVARD MEDICAL SCHOOL TO EXAMINE THE DEFINITION OF BRAIN DEATH. A definition of irreversible coma, in: J.A M A, 205:337-340, 1968.

ALMEIDA, Jr. \& Costa Jr. Lições de Medicina Legal, 14 ed., Ed. Nacional, 1977

ALMEIDA, Marcos de. Importância médico-legal da drepanocitose na morte súbita. Tese de Doutoramento em Medicina Legal da Escola Paulista de Medicina, S. Paulo, s/d.

Considerações de ordem ética sobre o início e o fim da vida. Tese de Livre-Docência em Medicina Legal, Medicina Social e do Trabalho e Deontologia Médica, da Faculdade de Medicina da USP, S. Paulo, 1988.

Morte: Uma nova proposta de reforma conceitual. Curso sobre Bioética.

ARBENZ,G. Compêndio de Medicina Legal. Ed. Ateneu, 1983.

ATOLKER, Careel J. The unconscious plaintiff: conscious ness a prerequisite for compensation for non pecuniary loss, in: International and Comparative Law Quaterly. London, 39(1): 82-100, jan. 1990.

BERLIN, I. Two Concepts of Liberty. Oxford, Clarendon Press, 1958.

BERLINGUER, Giovanni. Bioética da prevenção, in: Bioética, Brasília, 2 (2): 117 22, 1994.

BERISTAIN, Antonio- Bioética y nuevos "deveres"- derechos humanos, in: Revista Brasileira de Ciências Criminais. S.Paulo, 4 (13): 21-31, jan-mar, 1996.

BESPALI DE CONSENS, Yubarandt. Bioética y asistencia a los enfermos, in: Revista dos Tribunais, São Paulo, 85 (726): 475-81, abr. 1996.

BICHAT, Marie François-Xavier. Recherche sur la vie et la mort. Paris, 1800.

BLACK, P.M.L. Brain Death, in: New England Journal of Medicine, 299: 338-344, 1978.

BONNET,E.F.P. Medicina Legal. Buenos Aires, Lopez Ed., 2a ed., 1980, 2v.

BORRI, P apud Scigliano H; Berro, G \& Soiza. A Formas de muerte, in: Medicina Legal - Faculdad de Medicina de Montevideo, Montevidéu: 141-155, 1989.

BOUCHUT. Traité des signes de la mort et des moyens de prévenir les enterrements prematures. Paris, 1849. 
BROUARDEL, P.C. L' incertudes des signes de la mort et les inhumatios prématureés, in: La mort et la mort subite, $1^{\text {a }}$ ed. J. B. Baillière, 1895.

BYARD, Roger W Autoerotic death, in: The American Journal of Forensic Medicine and Pathology. New York, 12 (1): 74-6, mar. 1991.

CALABUIG, Gisbert J. A. Medicina Legal y Toxicologia. Barcelona, Masson Salvat Medicina Ed., 1994.

CASABONA, Carlos M.R. El medico y el Derecho penal. Barcelona, Bosh, 1981.

CANGER RODRIGUES, Armando. et alii, Problemas jurídicos e médico- legais do transplante do coração humano, in: Arquivos da Polícia Civil de S. Paulo, v.XXVI, $1^{\circ}$ sem. 1975.

CALLAHAN, Daniel. Genetic Knowledge: some legal and ethical questions. Cambridge, Cambridge University Press, 1996.

COHEN, Cláudio \& SEGRE, Marco. Breve discurso sobre valores, moral, eticidade e ética, in: Bioética. Brasília, 2 (I): 19-24, 1994.

Conselho Federal de Medicina. Resolução n. 1.346/91.

CHARLESWORTH, Max. La bioética en una sociedad liberal. Cambridge, Cambridge University Press, 1996.

CHIVELL, Wayne. Drugs and brain death: a legal perspective. Austrália, Adelaide, Coroner's Court, 1996.

DALY, David D. et alii - Current Pratice of Clinical Eletroencephalography. New York, Raven Press, s/d.

DAY, Lisa. Practical Limits to the Uniform Determination of Death Act, in: Ethics and Law. California, 1997.

DÉROBERT, L. et alii, Médicine Légale. Paris, Ed. Flammarion.

DEI, H. Daniel. Antropodicea: la question del hombre. Buenos Aires, Almagesto, 1977

ENGELHARDT, H.Tristram. The Foundations of Bioethics. Oxford, Oxford Univ. Press, 1995.

FÁVERO, Flamínio. Medicina Legal. S. Paulo, Martins Fontes, $8^{\text {a }}$ ed., 1966.

FRANÇA, Genival Veloso de. Direito Médico. S. Paulo, Fundo Ed. BYK, 1987.

Medicina Legal. Rio de Janeiro, Guanabara Koogan Ed., $4^{\text {a }}$ ed., 1995

Comentários ao Código de Ética Médica. Rio de Janeiro, Ed. Guanabara Koogan, 1997. 
FRANÇA, Rubens Limongi. O conceito de morte, diante do Direito ao transplante e do Direito hereditário, in: Revista dos Tribunais, S. Paulo, 84 (717): 65-74, jul. 1995.

FREUD, Sigmund. Obras completas. Madri, V.II, 1968.

GEBSATTEL, V E. Freiherr Von. Antropologia Médica. Madri, Ed. Rialp, AS., 1966.

GIACOMO, Perico. Problemi di Etica Sanitária. Milano, Ed. Ancora, 1985.

GIBBS, Nancy. Love and Let Die, in: Time, march 19: 32-38, 1990.

GOGLIANO, Daisy. Pacientes Terminais. Morte encefálica, in: Bioética 1: 145/156, 1993.

GOMES, H. Medicina Legal, $18^{\circ}$ ed., Freitas Bastos, 1977.

GUBERNATIS, G. Allgemeine Aspeckte der Organspende, in: Der Chirug, 67: 300000000-309, 1996.

ICARD, S. Le signe de la mort rẹelle en absence du médicin. Paris, Ed. A Maloine, 1907.

LACASSAGNE, A. Questions génerales relatives à mort, au cadavre et aux taches, in: Précis de Medicine Légale, Paris, Masson, 1909.

LAURENTI, Ruy. O atestado de óbito. Série Divulgação, São Paulo,1996.

LUTTGER, Hans. Medicina y Derecho Penal. Madri, Instit. de Criminologia de Madri, 1984.

MARCÍLIO, M. Luíza et alii. Ética na virada do século. Busca do sentido da vida. S. Paulo, Ed. LTR, 1997.

MARANHÃO, Odon Ramos. Curso Básico de Medicina Legal; São Paulo; $8^{\mathrm{a}}$ ed.; 1996.

MANTOVANI, Ferrando. I trapianti e la sperimentazione umana nel diritto italiano e straniero. Padova, CEDAM, 1974.

MEIRA, Clovis. Os legistas e as córneas, in: Revista dos Tribunais de Justiça do Pará. Belém, 34(49): 33-41, 1990.

MORAES, Irany Novaes. A morte vista do espelho, in: Jornal da USP de 3/4 mar., 1997, p. 2.

PEREIRA, Victor \& MARREY NETO, José Adriano. O momento da morte, in: RJDTACRIM, SP, (14): 15-8, abr./jun, 1992.

PESSINI, Leo. Distanasia: até quando investir sem agredir? In: Bioética, Brasília, 4(1): 31-43, 1996. 
SANVITO, Wilson Luiz. Propedêutica neurológica básica. S. Paulo, Gráfica Ed., 1981.

SEGRE, Marco \& COHEN, Claudio. org. - Bioética. S. Paulo, Ed. USP, 1995.

SGRECCIA, Elio. Manual de Bioética. I- Fundamentos de Ética Biomédica. S. Paulo, Ed. Loyola, 1992.

SILVA, Moacyr da. Compêndio de Odontologia Legal. S. Paulo, MEDSI ED., 1997.

SIMONIN, C. Medicina Legal Judicial. Trad. Esp. Barcelona, Ed Jims, 1962.

ROJAS, Nerio. Medicina Legal. Buenos Aires, Ed. Ateneo, 12º, 1987.

THOINOT, L. Diagnostic de la mort, in: Précis de Médicine Légale. Paris, Ed. Bailliére, t. I, 1913.

THOMASMA, David C. \& THOMASINE, Kushner. Birth to Death. Science and Bioethics. Cambridge, Cambridge University Press, 1996.

VANRELL, Jorge Paulete. Manual de Medicina Legal-Tanatologia. S. Paulo, LED Ed., 1996.

VAZ de ARRUDA, Paulo. Morte encefálica. Análise, in: Pediatria, 16(3): 102-112, 1994.

VEATCH, R. Death, dying and the biological revolution. Yale Univ. Press, 1976.

VEIGA DE CARVALHO, H., ALMEIDA, Marcos. SEGRE, Marco et alii. Compêndio de Medicina Legal. S. Paulo, Saraiva, 1987.

VIBERT. Signes et constatation de la mort Paris. Ed. Bailliére, 1900.

YALON, Irvin D. Psicoterapia Existencial. Barcelona, Ed. Herder, 1984.

ZACHARIAS, M. \& ZACHARIAS, E. Dicionário de Medicina Legal. Curitiba, EDUCA Ed. Univ. Campagnat, 1988.

ZARZUELA, José Lopes. Medicina Legal para concurso. S. Paulo, Angelotti, 1993.

ZUCKER, Majorie B. \& ZUCKER, Howard D. Medical Futility and the evaluation of life - sustaining interventions. Cambridge, Cambridge University Press, 1997. 